\title{
Invasions by ladybugs, ladybirds, and other predatory beetles
}

\author{
Edward W. Evans • António Onofre Soares • \\ Hironori Yasuda
}

Received: 14 December 2010/ Accepted: 11 May 2011

(C) International Organization for Biological Control (IOBC) 2011

\begin{abstract}
Species of predatory Coleoptera have become abundant in new geographic regions recently, raising concerns for invaded ecosystems. We address this topic by focusing on invasive alien ladybird beetles (Coccinellidae; known also as ladybugs). Humans appear directly or indirectly responsible for all or most ladybird invasions. Factors hypothesized to have promoted ladybird invasions include genetic diversity (e.g., for polymorphism), phenotypic plasticity, adaptation and genetic shift, generalized diet and habitat preferences, flexible life history and reproduction, large body size, and release from enemies. Factors such as climate, habitat and prey availability, and biotic resistance may sometimes
\end{abstract}

Handling Editor: Helen Roy.

E. W. Evans $(\bowtie)$

Department of Biology, Utah State University, Logan, UT 84322-5305, USA

e-mail: ted.evans@usu.edu

A. O. Soares

Department of Biology, CIRN, University of the Azores, Rua da Mãe de Deus, 13-A, 9501-801, Azores,

Ponta Delgada, Portugal

e-mail: onofre@uac.pt

H. Yasuda

Faculty of Agriculture, Yamagata University,

997-8555, Yamagata, Tsuruoka, Japan

e-mail: hyasuda@tds1.tr.yamagata-u.ac.jp prevent or slow ladybird invasions. Indigenous species (e.g., herbivores) may suffer from invasions, and biological control programs may be affected. Species of indigenous ladybirds throughout the world are reported to have declined in abundance following ladybird invasions, with increased competition and/or intraguild predation most often hypothesized or inferred. Similar recent studies especially of ground beetles (Carabidae) also make clear the potential of invasive alien predatory Coleoptera to disrupt invaded natural and agricultural ecosystems.

Keywords Competition - Habitat selection · Harmonia axyridis - Intraguild predation . Non-target effects · Species displacement

\section{Introduction}

Predatory Coleoptera, including aquatic species (e.g., DeMoor 1992), have great potential to become invasive alien species (IAS), rapidly attaining high numbers in new geographic regions. Species of Carabidae and Staphylinidae, for example, have invaded laurel forests of the Canary Islands, with little evidence either that habitat disturbance has promoted invasion, or that biotic resistance has slowed invasion (Arndt 2006; Arndt and Perner 2008). Several exotic ground beetles (Anisodactylus binotatus[F.], Laemostenus complanatus [Dejean], 
Paranchus albipes [F.] and Pterostichus vernalis [Panzer]) dominate many native and exotic forests in the Azores, in contrast to the endemic species that dominate similar communities in the Madeira Island Laurisilva (PAV Borges, pers. communication).

As IAS, predatory beetles may have large and diverse ecological and economic effects. Invasion by the alien carabid Trechus obtusus Erichson is associated with declines in abundances of endemic carabids (Mecyclothorax spp.) in Hawaii (Liebherr and Krushelnycky 2007). Invasion by another alien carabid Trechisibus antarcticus (Dejean) is associated with reduced abundance of the endemic herbivorous beetle, Hydromedion sparsutum (Muller) (Permylopidae), on the sub-Antarctic island of South Georgia (Ernsting et al. 1995). Since arriving at the sub-Antarctic island Iles Kerguelen a century ago, the carabid Merizodus soledadinus Jeannel has undergone reduction in body size that may reflect its negative impact on resident prey abundance (Laparie et al. 2010). Invasion of northwestern North America by Pterostichus melanarius (Illiger) (Carabidae) has been linked to negative impact on indigenous carabids in anthropogenic habitats but not in more natural habitats (Niemala and Spence 1991; Niemala et al. 1997). In field crop settings, this invasive, intraguild predator deters activity and predation on pest fly eggs by smaller carabid and staphylinid beetles, thereby undermining biological control (Prasad and Snyder 2004, 2006).

The invasiveness of predatory beetles has been illustrated in particularly striking fashion in recent decades by ladybird beetles (Coccinellidae), known also more simply in North America as ladybugs and in Europe and Asia as ladybirds. We highlight invasive alien ladybird beetles in this review, and focus on the large and rapidly growing literature concerning their histories of introduction, the factors hypothesized to affect their success, and their impacts on invaded ecological communities.

\section{Alarm over alien ladybirds}

Predatory ladybirds have been introduced repeatedly to new geographic regions since the late nineteenth century for biological control against scales, aphids, and other pest insects (e.g., Obrycki and Kring 1998). In North America alone, 179 species had been introduced by the mid 1980s (Gordon 1985). All of the eleven alien species of ladybirds in Europe were introduced as biological control agents (Roy and Migeon 2010). For many years, these introduction efforts led to few concerns that these ladybirds might have adverse effects on "non-target" resident species. In hindsight, this probably reflects that the most successful biocontrol introductions were of species (primarily coccid feeders; Dixon 2000) that are specialized in their diets and habits, and that most attempts to establish ladybirds with more generalized habits (e.g., many aphidophagous species) failed (e.g., Gordon 1985).

Attitudes changed significantly with the successful establishment in the 1970s and 1980s of Coccinella septempunctata L. (the seven spot ladybird, C7) throughout North America. Earlier introduction efforts in North America had not resulted in large populations that dominated local ladybird assemblages (Day et al. 1994; Harmon et al. 2007). Enthusiasm for spreading C7 widely during the 1970s (e.g., Angalet et al. 1979) was soon replaced by worry that it might adversely affect resident, indigenous ladybird species (e.g., Schaefer et al. 1987; Ehler 1990; Louda et al. 2003). Indeed, this insect was highlighted as an example of harmful alien species in the call that arose in the 1990s for new, tightened regulations for species importations and classical biological control (Ruesink et al. 1995; Simberloff and Stiling 1996). With concerns mounting over the potential for non-target effects of C7 in North America, this species came to be viewed as invasive (Elliott et al. 1996). Other alien ladybird species also now are frequently referred to as invasive to reflect especially the deep concern that their great abundance and widespread distribution in new geographic regions may adversely affect resident, indigenous species.

A second alien species, Harmonia axyridis (Pallas), soon followed C7 in spreading across North America (Tedders and Schaefer 1994; LaMana and Miller 1996). It too was quickly recognized as invasive in North America (e.g., Brown and Miller 1998), and subsequently throughout the world (Brown et al. 2011b). Its propensity to aggregate in homes to overwinter (and associated issues of reflex bleeding, biting behavior, and triggering of allergies), and its proclivity in late summer to feed on fruits (e.g., vineyard grapes) further cemented its 
designation as invasive (Koch and Galvan 2008). Concerns particularly over harmful effects on indigenous species diversity have similarly prompted identification of additional alien ladybird species as invasive or potentially so (e.g., Propylea quatuordecimpunctata L.; Lucas et al. 2007; Finlayson et al. 2008).

\section{Establishment, spread, and present status of ladybirds in new geographic regions}

Humans appear responsible in most or all cases for introductions of invasive alien ladybirds (e.g., Day et al. 1994; Roy and Migeon 2010). But often unclear is whether initial establishment has resulted directly from biological control releases, or by accident with human travel and trade (Day et al. 1994). A considerable lag between spatially separated releases and recoveries can heighten the confusion (LaMana and Miller 1996). This is illustrated well by the case histories of $\mathrm{C} 7$ and H. axyridis in North America.

Efforts to introduce C7 to North America beginning in 1957 and continuing through the early 1970 s appeared unsuccessful, with no recoveries made (Gordon 1985; Wheeler and Hoebeke 1995). But in 1973 populations likely arising from transoceanic shipping (Day et al. 1994; see also Minchin 2010) were discovered in eastern North America, and over the next five years more than half a million adults were collected and redistributed throughout the United States (Angalet et al. 1979). By 1986, C7 was well-established throughout northeastern and midwestern states (Schaefer et al. 1987). Its spread in the western United States was aided by further releases against the Russian Wheat Aphid during the 1980s (Prokrym et al. 1998), and it had became distributed throughout essentially all of North America by the early to mid 1990s.

From 1916 on, unsuccessful efforts repeatedly were made to introduce $H$. axyridis to North America for biological control (Gordon 1985). But again perhaps from shipping (Day et al. 1994), individuals appeared in southern Louisiana in 1988, far from sites where releases had been made a decade earlier (Tedders and Schaefer 1994). Similar recoveries were made in 1991 in the Pacific Northwest, and within two years $H$. axyridis had become very abundant in Oregon (LaMana and Miller 1996). These establishments in southeast and northwest North America appear independent (Lombaert et al. 2010). Both naturally and with human assistance (redistribution efforts for biological control), $H$. axyridis spread rapidly and soon came to inhabit essentially all of North America (and much of the world thereafter; Brown et al. 2011b).

As in their native ranges (Hodek and Honek 1996), in their invaded ranges $\mathrm{C} 7$ is most abundant in herbaceous habitats while $H$. axyridis is more arboreal. Both species occur in many semi-natural and natural habitats in invaded ranges, but tend to be most abundant in agricultural habitats and urban settings (e.g., Lucas et al. 2007; Brown et al. 2008b; Hesler and Kieckhefer 2008; Roy and Migeon 2010). Both species can be important biological control agents of aphid pests in North America (e.g., Tedders and Schaefer 1994; Brown and Miller 1998; Michaud 2002; Alyohkin and Sewell 2004; Heimpel et al. 2010), although in some cases their suppressive actions may simply substitute for those of displaced indigenous ladybirds (e.g., Evans 1991; Elliott et al. 1996; Obrycki et al. 2000).

Other ladybirds, less well studied than C7 and $H$. axyridis, have also succeeded in establishing and spreading in new geographic regions, with potentially adverse consequences. These species include P. quatuordecimpunctata and Hippodamia variegata (Goeze) in northeastern North America (Day et al. 1994; Ellis et al. 1999; Finlayson et al. 2008); Coccinella undecimpunctata L. and Adalia bipunctata (L.) in New Zealand (Dixon 2000); and Hippodamia convergens Guérin-Méneville and $H$. variegata (Goeze) in Chile (Grez et al. 2008).

As among introduced species in general (Simberloff and Gibbons 2004), initially invasive alien ladybird species may wane with time (Day and Tatman 2006; Harmon et al. 2007; Hesler and Kieckhefer 2008). For example, C. undecimpunctata became abundant in northeastern United States but thereafter mysteriously became rare (Harmon et al. 2007; Wheeler and Hoebeke 2008). In some settings [apple orchards (Brown 2003), potato fields (Alyokhin and Sewell 2004)], but not in others [alfalfa (Evans 2004)], the abundance of C7 in North America appears to have declined following establishment of $H$. axyridis. Thus it does not appear inevitable that ladybird species presently invasive will remain so over time. 


\section{Factors promoting ladybird invasions}

Ecologists have long sought attributes both of invasive species (invasiveness) and of invaded habitats and resident species (invasibility), and interactions between these sets of factors (Drake et al. 1989; Marco et al. 2002). Major attributes and interactions often hypothesized for invasive species may apply to invasive alien ladybirds in particular (e.g., Babendreier 2007; Hodek and Michaud 2008; Soares et al. 2008).

Colonizing species are often hypothesized to possess high genetic diversity. Interestingly, Krafsur et al. (2005) found no supporting evidence for this hypothesis among invasive alien ladybirds. Four introduced and six indigenous species in North America did not differ in their genetic diversities, and genetic variation among introduced species was uncorrelated with their invasive spread. Most genetic diversity in all species occurred within populations, with high gene flow resulting in little genetic differentiation among populations (Krafsur et al. 2005).

Phenotypic plasticity (i.e., variable trait expression among environments for a given genotype) may enhance colonizing ability. Indeed, phenotypic plasticity in development time and adult size is apparent in invasive populations of $H$. axyridis (Grill et al. 1997). Furthermore, genetic diversity for the expression of plasticity exists among individuals. Grill et al. (1997) suggest that genotypes expressing high levels of plasticity are especially predisposed to succeed in colonizing.

Adaptation and genetic shift within newly established colonies may spur invasion (Lawson-Handley et al. 2011). Lombaert et al. (2010) found that one invasive population of $H$. axyridis (in eastern North America) in particular was the source of colonists establishing in other parts of the world. This suggests that a single evolutionary shift occurred endowing emigrants from this population with superior invasive ability (Lombaert et al. 2010).

Ability to thrive in specific or diverse physical conditions also may foster species invasions. Roy and Migeon (2010) point out that tropical ladybirds introduced to greenhouses at high latitudes are unlikely to become invasive outside the protective confines of the greenhouse. In contrast, $H$. axyridis may be able to invade regions otherwise too cold for successful overwintering (Koch et al. 2004; Berkens et al. 2010a) by spending the winter in human houses (Labrie et al. 2008).

As often suggested for generalist predators, broad and flexible habitat use and diet may promote successful invasion. As noted above, for example, C7, A. bipunctata, H. axyridis and P. quatuordecimpunctata frequent many agricultural, urban, and natural habitats. Harmonia axyridis especially has a broad diet (Hodek and Honek 1996), and can have high conversion efficiency in consuming prey (Labrie et al. 2006). A broad, flexible diet may similarly promote invasion success of C7. As a dominant, invading species of North American alfalfa fields, for example, it is distinctive both in its ability to tolerate low aphid abundance (Kajita et al. 2009), and in its responsiveness to alternative prey (Evans and Toler 2007). Adalia bipunctata is also flexible in its diet, and adapted rapidly over several generations in a laboratory selection experiment to more effectively exploit Aphis fabae, a nutritionally poor prey (Rana et al. 2002).

Both flexibility and high output in reproductive performance may contribute to invasion. For example, traits suggested as predisposing $\mathrm{C} 7$ and $H$. axyridis to be successful invaders include high rates of fecundity (Soares et al. 2008; Kajita and Evans 2010), capacity to be multivoltine (Babendreier 2007; Brown et al. 2008a; Hodek and Michaud 2008), inhibition of oviposition in the presence of other ladybirds (Hodek and Michaud 2008), ability to resorb eggs (Osawa 2005; Kajita and Evans 2009), and readiness to reproduce rapidly under diverse conditions (e.g., Hodek and Honek 1996; Evans 2000; Hodek and Michaud 2008).

Large body size may also promote success of invasive species (e.g., Roy et al. 2002). The invasive success of $H$. axyridis, and $\mathrm{C} 7$ may be linked to their large size, which in turn is associated with high potential reproductive rate and dispersal ability that promote their rapid spread through new geographic regions. $\mathrm{C} 7$, for example, has greater fecundity when aphid density is high than do the smaller indigenous ladybirds that it has displaced in alfalfa fields of western North America (Kajita and Evans 2010).

Genetically based polymorphism may be important in enabling invasive species to exploit multiple, 
finely graded habitats and micro-niches. Polymorphism is maintained when different genotypes are selectively favoured in different parts of the environment, or at different times (Soares et al. 2005; Michie et al. 2010). Indigenous populations of $H$. axyridis are polymorphic, with differences in relative abundance of phenotypes correlated with climatic, geological and geographic conditions (Komai 1956; Kryltsov 1956; Tan 1946). Phenotypes defined by coloration and elytral patterns differ also in characteristics such as voracity, longevity, and reproductive capacity (Soares et al. 2001). Polymorphism of this species occurs also in Europe, and may promote invasion (Majerus et al. 2006; Brown et al. 2008b; Adriaens et al. 2008).

Melanic phenotypes of $H$. axyridis occur especially in boreal forests, likely reflecting their adaptive advantage in colder climates (Koch et al. 2006). Higher body temperature of dark versus light coloured morphs at low ambient temperature results in increased activity, voracity, developmental rate, reproduction and ultimately fitness (e.g., Brakefield 1984; Stewart and Dixon 1989; De Jong et al. 1996). The optimum temperature for predation by adults is lower for the nigra than for the aulica phenotype (Soares et al. 2003). Habitat differences among morphs of polymorphic ladybirds also may reflect preferences for aphid species that vary in nutritional value among ladybird morphs (e.g., see Soares et al. 2004). The relative frequency of elytral phenotypes in $H$. axyridis in Japan varies according to microgeographic variation, specifically the aphid prey present on host plants (Komai and Hosino 1951).

Finally, the enemy release hypothesis (i.e., that aliens thrive by escaping from natural enemies "left behind"; Roy et al. 2011) may apply for invasive alien ladybirds. As newcomers in North America, H. axyridis and $\mathrm{C} 7$ contrast with indigenous ladybirds in having more immunity to North American pathogens (the fungus Beauveria bassiana [Balsamo] Vuillemin as well as nematodes; Shapiro-Ilan and Cottrell 2005; Cottrell and Shapiro-Ilan 2008). Although attacked by Dinocampus coccinellae (Schrank) (Braconidae), H. axyridis suffers less from this parasitoid than do indigenous coccinellids in North America and Europe (Hoogendoorn and Heimpel 2002; Koyama and Majerus 2008; Berkvens et al. 2010b; Firlej et al. 2010). Over time, adaptation and opportunity may lead endemic natural enemies to become more effective in suppressing invasive alien ladybirds. One such natural enemy in Europe may be the sexually transmitted mite Coccipolipus hippodamiae (McDaniel and Morrill), a species first documented in North America to infect $H$. axyridis under field conditions (Riddick 2010). Infection of $H$. axyridis by this mite, as now confirmed in the field in Poland and likely arising from interspecific mating with infected indigenous ladybirds, results in female sterility (Rhule et al. 2010). Infection by the mite of $H$. axyridis males in natural populations in North America was associated with intensity of infection by Hesperomyces virescens Thaxter (Riddick 2010), a parasitic fungus found to attack $H$. axyridis (even more so than co-occurring indigenous ladybirds) in eastern North America (Riddick and Schaefer 2005; Harwood et al. 2006).

\section{Limiting factors for ladybird invasions: case histories}

Ladybirds invasive elsewhere have failed to establish in the Azores although these islands seem vulnerable to invasion (Soares et al. 2008). Ecological release occurs frequently on islands, perhaps because weakly organized insular communities offer relatively little biotic resistance to invasion (Borges et al. 2006; Cox, 2004; Whittaker and Fernández-Palacios 2009). This may be true of the Azores Island where $60 \%$ of beetle species (70\% for ladybirds) are alien (Borges et al. 2006; Soares, 2010). Harmonia axyridis and C7, however, are absent from the islands (Soares et al. 2008; Soares 2010), perhaps for similar reasons as to why large vertebrates are often absent from islands (Cox 2004).

Floral and faunal features of Azorean habitats may reduce their invasibility by large ladybirds. The habitats are, in general, small, fragmented and of anthropogenic origin (e.g., grasslands grazed by cattle). Arboreal habitats may support too few aphids for $H$. axyridis (Borges et al. 2006). Aphids are common in other plant communities (e.g., coastal and wetland vegetation; Borges et al. 2006; Soares et al. 2008), but these habitat fragments may be too small to support the large-bodied $H$. axyridis and C7. Indeed these habitats are dominated by smaller 
ladybird species such as Scymnus, Rhyzobius and C. undecimpunctata.

The establishment of $H$. axyridis in the Azores may also be hampered by the insufficiently low temperature regime during winter (when essential food resources may be lacking). This may undermine this species' overwintering strategy (Soares et al. 2008). Because temperatures fail to drop enough in Azorean winters to encourage diapause (Watanabe 2002; Hodek and Honek 1996; Berkvens et al. 2010a), individuals of $H$. axyridis may not survive well in the absence of sufficient prey.

In Japan, nine alien species of ladybirds recently have been introduced accidentally (Sakuratani 2002), joining the 180 resident species of ladybirds known to occur (Sasaji 1982). One alien, A. bipunctata, was first observed in 1993 at Osaka (Sakuratani 1994). It has since expanded its range in Japan slowly and remains limited in its distribution (Toda and Sakuratani 2006). It occurs on shrubs that it shares with seven indigenous ladybird species, including the well-known intraguild predator $H$. axyridis (Toda and Sakuratani 2006). The abundance of A. bipunctata notably declined in North America following the introduction of H. axyridis (Brown and Miller 1998; Brown 2003) and intraguild predation may be implicated (Yasuda et al. 2004). Laboratory studies in Japan similarly suggested negative effects on A. bipunctata could occur from interactions with large indigenous ladybirds, particularly $H$. axyridis (Kajita et al. 2000, 2006a; Toda and Sakuratani 2006; Matsumoto and Sakuratani 2006; Sato et al. 2009). On the other hand, A. bipunctata sometimes consumed the smaller species, P. japonica (Kajita et al. 2006a).

Intraguild predation (e.g., by $H$. axyridis) may be slowing the rate with which $A$. bipunctata is invading Japan. Nonetheless the univoltine A. bipunctata may be able to slowly expand its distribution because its life cycle is asynchronous with the life cycle of the bivoltine $H$. axyridis and the life cycles of other indigenous ladybirds, thereby allowing it to escape direct interactions to some degree (Sakuratani et al. 2000; Toda and Sakuratani 2006). Furthermore, overwintering adults of $A$. bipunctata lay eggs earlier in the spring than adults of $H$. axyridis do, providing additional escape in time from adverse, interspecific larval interactions (Toda and Sakuratani 2006).

\section{Ecological impacts of ladybirds in new geographic regions}

A variety of potentially adverse ecological effects of invasive alien ladybirds have received attention.

\section{Effects on biological control programs}

Ironically, alien ladybirds introduced on purpose may undermine biological control programs. Harmonia axyridis readily consumes other natural enemies of aphids such as lacewing and fly (Cecidomyiid) larvae (e.g., Gardiner and Landis 2007), parasitoids (in aphid mummies; e.g., Chacon et al. 2008), and insectpathogenic fungi (in aphid cadavers; e.g., Roy et al. 2008). There is worry therefore that such intraguild predation could disrupt biological control of pest aphids. But at least in the case of soybean aphid outbreaks in North America, recent field tests indicate that greatest aphid suppression occurs when both $H$. axyridis and other natural enemies are present (Gardiner and Landis 2007; Chacon et al. 2008).

Invasive alien ladybirds also can indirectly affect other natural enemies. Just the potential for intraguild predation may deter other natural enemies. The parasitoid Aphidius ervi Haliday, for example, avoids searching in patches of aphids recently visited by $\mathrm{C} 7$ (Taylor et al. 1998; Nakashima and Senoo 2003). Effects even more indirect can emerge from ladybird consumption of aphids. For example, parasitism of the alfalfa weevil can be undercut when aphids in alfalfa are consumed in large numbers by $\mathrm{C} 7$, thereby denying weevil parasitoids access to aphid honeydew that serves as an important source of nutrition for foraging females (Evans and England 1996).

Introduced ladybirds could interfere with biological control programs for weeds. Cryptolaemus montrouzieri Mulsant, for example, was found to be a major predator of the cochineal insect Dactylopius opuntiae (Cockerell) introduced to South Africa and Mauritius for control of prickly pear cacti (Opuntia spp.), and the coccinellid was judged to have interfered significantly with the biological control efforts (Goeden and Louda 1976). Sebolt and Landis (2004) report $H$. axyridis as a common predator co-occurring in Michigan wetlands with Galerucella calmariensis L. (Chrysomelidae). Adults of H. axyridis readily consume young larvae of this biocontrol 
agent of purple loosestrife. It is unclear, however, whether significant biotic interference results for the establishment and spread of the herbivore (Sebolt and Landis 2004).

Effects on indigenous herbivores

Diverse species, in addition to targeted pest aphids and scales, can be vulnerable to attack by invasive alien ladybirds (e.g., Evans 2009). The potential adverse impact of $\mathrm{C} 7$ on population size of endangered lycaenid butterflies in remnant North American habitats has been explored by field observations and modeling (Horn 1991; Schellhorn et al. 2005). Similarly, the susceptibility of monarch butterfly (Danaus plexippus [L.]) caterpillars to predation by $H$. axyridis in the north central United States has been demonstrated in laboratory and field cage experiments (Koch et al. 2003, 2005). Rates of predation by invasive alien ladybirds in natural populations of Lepidoptera and other non-target herbivores, however, remain to be quantified and evaluated. One suggestive study by Rand and Louda (2006) found unusually high numbers of adult ladybirds (mostly of indigenous species, but also including individuals of $\mathrm{C} 7$ and $\mathrm{H}$. axyridis) in native grasslands of Nebraska that were surrounded by large areas of cropland from which the ladybirds likely dispersed upon maturing. Aphid densities were dramatically reduced on an indigenous thistle in these grassland remnants when predators including the abundant ladybirds were allowed access, versus when the predators were denied access by caging the host plant (Rand and Louda 2006).

Effects on indigenous ladybirds

\section{Evidence of adverse effects}

The first hints of trouble from $\mathrm{C} 7$ came from eastern North America with a decline in numbers of Coccinella novemnotata Herbst noted in Maryland nurseries (Staines et al. 1990). Wheeler and Hoebeke (1995) documented this pattern across the landscape of northeastern North America, and Harmon et al. (2007) concluded that in recent decades C. novemnotata appears to have declined in numbers throughout North America. As both sets of authors noted, however, factors other than the introduction of $\mathrm{C} 7$ (e.g., changes in land use) also could have caused the apparent demise of C. novemnotata. Long-term and large-scale surveys by others have also documented population declines for some indigenous ladybird species in various habitats in North America following the introduction of C7 (Elliott et al. 1996; Ellis et al. 1999; Turnock et al. 2003; Alyokhin and Sewell 2004; Evans 2004). While most studies have focused on agricultural settings (e.g., alfalfa fields), some have reported similar results for natural and seminatural settings (e.g., Turnock et al. 2003).

Upon its establishment in the Pacific Northwest of North America in the 1980s and early 1990s, $H$. axyridis quickly increased in numbers (LaMana and Miller 1996). A similarly spectacular rise to dominance in diverse crops (many herbaceous) occurred over the decade following establishment of $H$. axyridis in eastern North America (Lucas et al. 2007). Associated declines in numbers of indigenous ladybirds were documented in diverse habitats (mostly agricultural) in Michigan (Colunga-Garcia and Gage 1998), apple orchards of West Virginia (Brown and Miller 1998; but see also Brown 2003), and Florida citrus orchards (Michaud 2002).

A long-term decline in numbers of $A$. bipunctata in Michigan, apparently already underway in 1989 and perhaps initiated by the prior arrival of $\mathrm{C} 7$, continued with the arrival of $H$. axyridis (Colunga-Garcia and Gage 1998). This same pattern emerges consistently from surveys of $A$. bipunctata populations throughout North America (Harmon et al. 2007).

Attention has been drawn also in Europe to the similar plight of $A$. bipunctata and other indigenous species (e.g., C7, C. undecimpunctata and P. quatuordecimpunctata) with the establishment of $H$. axyridis (e.g., Lynch et al. 2001; Sato and Dixon 2004; Soares and Serpa 2007; Adriaens et al. 2008; Ware and Majerus 2008; Ware et al. 2009; Brown et al. 2011a). Burgio et al. (2002) note, however, that negative impact on $A$. bipunctata from $H$. axyridis may be softened because intraguild predation does not outweigh cannibalism in interactions between these two species. In South America, timed visual sampling conducted weekly throughout the year in secondary forest both before and after the 2002 arrival of $H$. axyridis in Parana, Brazil, revealed declines of formerly common ladybirds (Martins et al. 2009). 
Adverse effects on indigenous ladybirds by invasive alien ladybirds other than $\mathrm{C} 7$ and $H$. axyridis have not been widely studied. As further discussed below, Finlayson et al. (2008) found that formerly abundant ladybirds occur in very low numbers in diverse habitats in Maine now occupied by a complex of invasive alien ladybirds, including especially $P$. quatuordecimpunctata. The introduced $H$. variegata may be replacing the indigenous Eriopis connexa (Germar) in alfalfa fields of central Chile. The former species was much rarer than the latter species in 1993 but this pattern had become reversed by 2008 (Grez 1997; Grez et al. 2008; Grez et al. in review).

The collective results of many surveys certainly suggest significant declines in abundance of various indigenous ladybird species throughout the world following the establishment of alien species. Nonetheless, before/after comparisons must be made with caution, both because additional factors (e.g., changes in land use) may be important and because the species composition and abundance of ladybird assemblages at specific locations can vary markedly and often unpredictably over time, often as influenced by fluctuating prey availability (e.g., Day and Tatman 2006). Thus, Harmon et al. (2007) did not find a consistent, significant decline in the abundance of indigenous ladybirds (all species combined) following the establishment of $\mathrm{C} 7$ and H. axyridis among North American studies that quantified ladybird abundances. These caveats highlight the need for additional studies that measure long term prey and predator abundance (with the latter measured for each ladybird species in an assemblage) to evaluate further the extent of hypothesized adverse effects on indigenous ladybirds.

\section{Proposed mechanisms}

Attention has focused particularly on four potential ecological mechanisms (involving either direct or indirect interactions) that could be driving ecological displacements of indigenous ladybirds: competition among co-occurring individuals (especially scramble competition for food among larvae), intraguild predation (sometimes viewed as an extreme form of interference competition), habitat shift or compression (habitat selection by adults as affected indirectly by competition), and interspecific hybridization. An intriguing additional mechanism, sharing of natural enemies (parasitoids attacking ladybirds), may enhance rather than depress indigenous ladybird abundance. We review here briefly studies addressing these mechanisms. The diverse results call for additional studies.

Competition among co-occurring individuals. Invasive alien ladybirds may prevail in foraging alongside indigenous ladybirds for aphids. Tests to date provide mixed support (the special case of intraguild predation is treated below).

In laboratory tests, Evans (1991) found no difference in the strengths of intraspecific and interspecific competition between equally sized larvae of C7 and the North American indigenous species, H. convergens. Obrycki et al. (1998a) reached a similar conclusion in field tests for $\mathrm{C} 7$ and Coleomegilla maculata (De Geer). Analysis of mean adult body sizes over time provided no indication that indigenous ladybird individuals became smaller (from increased scramble competition during larval stages) following the establishment of C7 in western North America (Evans 2000).

In Japan, where $H$. axyridis is indigenous and the much smaller A. bipunctata is an alien, strong and asymmetric interspecific competition resulted in slower development of $A$. bipunctata when $H$. axyridis was present in laboratory tests with abundant prey (Kajita et al. 2000). But development rate and weight gain of larvae of the North American species, Coccinella transversoguttata richardsoni Brown and $H$. convergens, did not differ when paired with a conspecific larva versus a larva of $H$. axyridis or C7 (Yasuda et al. 2004). The presence of $H$. axyridis larvae in field cages did not affect larval survival or weight gain of C. maculata significantly, perhaps because larvae of the latter species avoided interactions with $H$. axyridis by modifying where in the cages they searched (Hoogendoorn and Heimpel 2004).

Adults of C. maculata and C7 did not modify their vertical distributions on apple trees in response to the presence of H. axyridis adults (Lucas et al. 2002). In laboratory tests with abundant prey, however, females of the Azorean indigenous ladybird C. undecimpunctata laid fewer eggs in the presence of a $H$. axyridis female (but not a conspecific female) than when alone, perhaps as the result of interference competition (Soares and Serpa 2007). Similarly, females of $A$. bipunctata provided with aphids in excess laid fewer eggs when paired with a female 
of $H$. axyridis or $\mathrm{C} 7$ versus with a conspecific female (Kajita et al. 2006b).

Intraguild predation complicates the assessment of scramble competition among larvae of invasive alien and indigenous ladybirds. In laboratory tests with few prey, survival of $C$. maculata larvae was reduced when paired with larvae of $\mathrm{C} 7$ or $\mathrm{H}$. axyridis versus conspecific larvae, but it is unclear whether this resulted from scramble competition for aphids, intraguild predation, or both (e.g., increased intraguild predation of $C$. maculata weakened by reduced consumption of prey) (Obrycki et al. 1998b; Moser and Obrycki 2009).

Intraguild predation (IGP). Comprehensive reviews emphasize the potential importance of IGP in interactions both of invasive alien and indigenous ladybirds, and of members of aphidophagous guilds more generally (Lucas 2005; Pell et al. 2008). Interest in whether a basic asymmetry in IGP favors invasive alien ladybirds over indigenous species began in North America with the invasion of C7 (e.g., Evans 1991; Obrycki et al. 1998b). Such interest intensified with the spread of H. axyridis across North America, stimulated by field and laboratory studies of IGP involving this species both in its indigenous Japan (e.g., Yasuda and Shinya 1997; Yasuda et al. 2001) and in its new range (e.g., Cottrell and Yeargan 1998; Michaud 2002). Laboratory studies comparing $\mathrm{C} 7$ and $H$. axyridis larval interactions with indigenous ladybird species revealed $H$. axyridis to be much the greater threat to indigenous species in North America as an intraguild predator (Yasuda et al. 2004; Snyder et al. 2004). Laboratory studies in Europe also demonstrated the strong tendency of $H$. axyridis to prey on larvae of indigenous ladybirds (e.g., Burgio et al. 2002; Sato and Dixon 2004; Félix and Soares 2004; Nóia et al. 2008; Ware and Majerus 2008). In particular, the large size and aggressive behavior of $H$. axyridis as well as its physical and chemical defenses (Slogget et al. 2011) make it a strong top predator among ladybirds.

Interactions based on IGP, cannibalism, and competition appear to be symmetrical between $H$. variegata and E. connexa. Hence these mechanisms likely do not explain replacement of the former by the latter species in alfalfa fields of central Chile (Grez et al. personal communication).

Ladybird eggs as well as larvae are vulnerable to IGP. The extent of egg predation depends on the defensive alkaloids present in eggs of individual species (e.g., Agarwala and Dixon 1992; Sloggett and Davis 2010). A striking asymmetry occurs between $H$. axyridis and many ladybird species. In general, eggs of $H$. axyridis appear better defended against predation by other ladybirds, including indigenous ladybirds in eastern North America, than vice versa (Cottrell 2007), although interesting exceptions occur (e.g., Ware and Majerus 2008).

As noted by various authors (e.g., Dixon 2000; Yasuda et al. 2004; Pell et al. 2008; Weber and Lundgren 2009), laboratory studies only outline the potential importance of IGP in the field, and indeed may exaggerate such potential. With some exceptions (e.g., Yasuda and Shinya 1997), it is not well-known how frequently IGP occurs among ladybirds in natural settings. Increasing application of molecular techniques (e.g., DNA analyses of gut contents, and detection of exogenous alkaloids) will shed light on this key question (e.g., Aebi et al. 2011; Hautier et al. 2008).

Habitat shift (compression). Population declines of indigenous species in given habitats may reflect the indirect effects of invasive species on habitat selection (Evans 2000). The habitat compression or habitat shift hypothesis from optimal foraging theory (MacArthur and Wilson 1967; Rosenzweig 1991) predicts that, if an invasive alien ladybird sufficiently reduces the prey base, indigenous ladybirds may abandon the habitat to forage elsewhere. In alfalfa fields where aphid and indigenous ladybird densities had both declined after establishment of $\mathrm{C} 7$, the experimental creation of local aphid outbreaks caused indigenous ladybirds to reappear in substantial numbers (Evans 2004). Alyohkin and Sewell (2004) found that indigenous ladybird and aphid densities were low in Maine potato fields following the establishment of $H$. axyridis. Intriguingly, however, clear and consistent declines were observed only for indigenous ladybirds, and not for aphids, with the earlier establishment of $\mathrm{C} 7$.

Habitat shift may be operating on ladybirds in alfalfa fields in central Chile. The indigenous species E. connexa is more sensitive and responsive to low aphid abundance than is the exotic $H$. variegata. Within small prey patches, both body mass and fecundity of E. connexa were reduced, but $H$. variegata preferentially allocated food to maintaining reproduction versus body mass. Thus the indigenous species 
may prefer to forage in large aphid colonies while $H$. variegata forages more evenly among different prey patch sizes and thereby gains advantage in exploiting patches less visited by the potential competitor E. connexa (Grez et al. personal communication).

The habitat shift hypothesis highlights the possibility of refuge habitats for indigenous ladybirds (i.e., habitats weakly invaded by introduced species; Evans 2000). Finlayson et al. (2008), however, found introduced ladybirds (seven species combined) were widespread and abundant in nonagricultural as well as agricultural habitats throughout Maine, while indigenous ladybirds were relatively low in abundance everywhere. These results reflected the very high abundance of one invasive alien ladybird in particular, $P$. quatuordecimpunctata, in multiple habitats $[\mathrm{C} 7$, in contrast, tended to reach highest numbers in crops, as it does in western North America (Evans 2000)]. In South Dakota, C7 and H. axyridis were present in many habitats but abundant in only a few [including grass and alfalfa; Hesler and Kieckhefer (2008)]. Refuge habitats and landscapes may occur in the Midwestern United States, where indigenous ladybirds have been largely displaced by $H$. axyridis and C7 within widely planted soybean fields: indigenous species thrive best in grassland dominated landscapes that may be resistant to build-up in numbers especially of $H$. axyridis (Gardiner et al. 2009).

Interspecific hybridization. Another hypothesis for indigenous ladybird declines is hybridization with introduced ladybirds, as observed with other invasive species (e.g., Rhymer and Simberloff 1996; Snyder and Evans 2006). In the case of $C 7$, however, evidence to date for such is negative. Both sexes of $\mathrm{C} 7$ mated with C. transversoguttata when paired in the laboratory, but females in such interspecific pairings did not produce fertile eggs (EW Evans, unpublished data). But interspecific matings can result also in transmission of sexually transmitted diseases and parasites (Majerus 1997). Effects can be adverse for invasive alien as well as indigenous species (Rhule et al. 2010).

Sharing of parasitoids. As illustrated by mites and ladybirds (Rhule et al. 2010), sharing of natural enemies with invasive alien ladybirds sometimes can have negative effects on indigenous ladybirds. But a positive rather than negative effect can arise if such sharing results in dilution of attack on indigenous ladybirds. Hoogendoorn and Heimpel (2002) conclude that $H$. axyridis is a relatively unsuitable host for the widespread coccinellid parasitoid D. coccinellae, Hence this invasive alien ladybird may serve as an egg sink for this parasitoid, which may lead to reduced parasitism of the indigenous C. maculata (Hoogendoorn and Heimpel 2002). Koyama and Majerus (2008) and Firlej et al. (2010) draw similar conclusions regarding the indigenous $\mathrm{C} 7$ in Britain and C. maculata in eastern Canada, but note that natural selection may favor adaptation of the parasitoid over the long term to its new host, $H$. axyridis.

\section{Concluding remarks}

The Coccinellidae have received most attention among predatory Coleoptera in recent years as IAS, especially because of $H$. axyridis. But as noted at the outset, other predatory beetles such as the Carabidae and Staphylinidae also have invaded new geographic regions, and the broad implications of these invasions are not yet well understood. As the case of Coccinellidae in particular illustrates, there is pressing need to study and evaluate more fully the ecological and economic consequences of invasions by predatory Coleoptera.

Acknowledgments We thank Helen Roy, Remy Poland, Lori Lawson-Handley and Patrick De Clercq for their kind invitation and encouragement to prepare this review, and two anonymous reviewers for their helpful comments and suggestions on the manuscript.

\section{References}

Adriaens T, Gomez GSM, Maes D (2008) Invasion, habitat preferences and phenology of the invasive ladybird Harmonia axyridis in Belgium. BioControl 53:69-88

Aebi A, Brown PMJ, De Clercq P, Hautier L, Howe AG, Ingels B, Ravn H-P, Sloggett JJ, Zindel R, Thomas A (2011) Detecting arthropod intraguild predation in the field. BioControl. doi:10.1007/s10526-011-9378-2

Agarwala BK, Dixon AFG (1992) Laboratory study of cannibalism and interspecific predation in ladybirds. Ecol Entomol 17:303-309

Alyokhin A, Sewell G (2004) Changes in a lady beetle community following the establishment of three alien species. Biol Invasions 6:463-471

Angalet GW, Tropp JM, Eggert AN (1979) Coccinella septempunctata in the United States: recolonizations and notes on its ecology. Environ Entomol 8:896-901

Arndt E (2006) Niche occupation by invasive ground-dwelling predator species in Canarian laurel forests. Biol Invasions 8:893-902 
Arndt E, Perner J (2008) Invasion patterns of ground-dwelling arthropods in Canarian laurel forests. Acta Oecologia 34:202-213

Babendreier D (2007) Pros and cons of biological control. Ecol Stud 193:403-418

Berkvens N, Bale JS, Berkvens D, Tirry L, De Clercq P (2010a) Cold tolerance of the harlequin ladybird Harmonia axyridis in Europe. J Insect Physiol 56:438-444

Berkvens N, Moens J, Berkvens D, Samih MA, Tirry L, De Clercq P (2010b) Dinocampus coccinellae as a parasitoid of the invasive ladybird Harmonia axyridis in Europe. Biol Control 53:92-99

Borges I, Soares AO, Hemptinne J-L (2006) Abundance and spatial distribution of aphids and scales select for different life histories in their ladybird beetle predators. J Appl Entomol 130:461-464

Brakefield PM (1984) Ecological studies on the polymorphic ladybird Adalia bipunctata in The Netherlands. II. Population dynamics, differential timing of reprodution and thermal melanism. J Anim Ecol 53:775-790

Brown MW (2003) Intraguild responses of aphid predators on apple to the invasion of an exotic species, Harmonia axyridis. BioControl 48:141-153

Brown MW, Miller SS (1998) Coccinellidae (Coleoptera) in apple orchards of eastern West Virginia and the impact of invasion by Harmonia axyridis. Entomol News 109:136-142

Brown PMJ, Adriaens T, Bathon H, Cuppen J, Goldarazena A, Hagg T, Kenis M, Klausnitzer BEM, Kovar I, Loomans AJM, Majerus MEN, Nedved O, Pedersen J, Rabitsch W, Roy HE, Ternois V, Zakharov IA, Roy DB (2008a) Harmonia axyridis in Europe: spread and distribution of a non-native coccinellid. BioControl 53:5-21

Brown PMJ, Roy HE, Rotheray P, Roy DB, Ware RL, Majerus MEN (2008b) Harmonia axyridis in Great Britain: analysis of the spread and distribution of a non-native coccinellid. BioControl 53:55-67

Brown PMJ, Frost R, Doberski J, Sparks T, Harrington R, Roy HE (2011a) Decline in native ladybirds in response to the arrival of Harmonia axyridis: early evidence from England. Ecol Entomol 36:231-240

Brown PMJ, Thomas CE, Lombaert E, Jeffries DL, Estoup A, Lawson Handley J-L (2011b) The global spread of Harmonia axyridis (Coleoptera: Coccinellidae): distribution, dispersal and routes of invasion. BioControl. doi:10. 1007/s10526-011-9379-1

Burgio G, Santi F, Maini S (2002) On intra-guild predation and cannibalism in Harmonia axyridis (Pallas) and Adalia bipunctata L. (Coleoptera: Coccinellidae). Biol Control 24:110-116

Chacon JM, Landis DA, Heimpel GE (2008) Potential for biotic interference of a classical biological control agent of the soybean aphid. Biol Control 46:216-225

Colunga-Garcia M, Gage SH (1998) Arrival, establishment, and habitat use of the multicolored Asian lady beetle (Coleoptera: Coccinellidae) in a Michigan landscape. Environ Entomol 27:1574-1580

Cottrell TE (2007) Predation by adult and larval lady beetles (Coleoptera: Coccinellidae) on initial contact with lady beetle eggs. Environ Entomol 36:390-401

Cottrell TE, Shapiro-Ilan DI (2008) Susceptibility of endemic and exotic North American ladybirds (Coleoptera:
Coccinellidae) to endemic fungal entomopathogens. Eur J Entomol 105:455-460

Cottrell TE, Yeargan KV (1998) Intraguild predation between an introduced lady beetle, Harmonia axyridis (Coleoptera: Coccinellidae), and a native lady beetle, Coleomegilla maculata (Coleoptera: Coccinellidae). J Kans Entomol Soc 71:159-163

Cox GW (2004) Alien species and evolution: the evolutionary ecology of exotic plants, animals, microbes, and interacting native species. Island Press, Washington

Day WH, Tatman KM (2006) Changes in abundance of native and adventive Coccinellidae (Coleoptera) in alfalfa fields, in northern New Jersey (1993-2004) and Delaware (1999-2004), U.S.A. Entomol News 117:491-502

Day WH, Prokrym DR, Ellis DR, Chianese RJ (1994) The known distribution of the predator Propylea quatuordecimpunctata (Coleoptera: Coccinellidae) in the United States, and thoughts on the origin of this species and five other exotic lady beetles in eastern North America. Entomol News 105:245-256

De Jong PW, Gussekloo SWS, Brakefield PM (1996) Differences in thermal balance, body temperature and activity between non-melanic and melanic two-spot ladybird beetles (Adalia bipunctata) under controlled conditions. J Exp Biol 199:2655-2666

DeMoor FC (1992) Factors influencing the establishment of aquatic insect invaders. Trans Roy Soc S Afr 48:141-158

Dixon AFG (2000) Insect predator-prey dynamics. Ladybird beetles and biological control. Cambridge University Press, Cambridge

Drake JA, Mooney HA, di Castri F, Groves RH, Kruger FJ, Rejmanek M, Williamson M (eds) (1989) Biological invasions: a global perspective. Wiley, Chichester

Ehler LE (1990) Introduction strategies in biological control of insects. In: Mackauer M, Ehler LE, Roland J (eds) Critical issues in biological control. Intercept Ltd, Andover, pp 111-134

Elliott N, Kieckhefer R, Kauffman W (1996) Effects of an invading coccinellid on native coccinellids in an agricultural landscape. Oecologia 105:537-544

Ellis DR, Prokrym DR, Adams RG (1999) Exotic lady beetle survey in northeastern United States: Hippodamia variegata and Propylea quatuordecimpunctata (Coleoptera: Coccinellidae). Entomol News 110:73-84

Ernsting G, Block W, MacAlister H, Todd C (1995) The invasion of the carnivorous carabid beetle Trechisibus antarticus on South Georgia (sub-Antarctic) and its effect on the endemic herbivorous beetle Hydromedion spasutum. Oecologia 103:34-42

Evans EW (1991) Intra versus interspecific interactions of lady beetles (Coleoptera: Coccinellidae) attacking aphids. Oecologia 87:401-408

Evans EW (2000) Morphology of invasion: body size patterns associated with establishment of Coccinella septempunctata in western North America. Eur J Entomol 97:469-474

Evans EW (2004) Habitat displacement of native North American ladybirds by an introduced species. Ecology 85:637-647

Evans EW (2009) Lady beetles as predators of insects other than Hemiptera. Biol Control 51:255-267 
Evans EW, England S (1996) Indirect interactions in biological control of insects: pests and natural enemies in alfalfa. Ecol Appl 6:920-930

Evans EW, Toler T (2007) Aggregation of polyphagous predators in response to multiple prey species: ladybirds (Coleoptera: Coccinellidae) foraging in alfalfa. Popul Ecol 49:29-36

Félix S, Soares AO (2004) Intraguild predation between the aphidophagous ladybird beetles Harmonia axyridis and Coccinella undecimpunctata (Coleoptera: Coccinellidae): the role of body weight. Eur J Entomol 101:237-242

Finlayson CJ, Landry KM, Alyokhin AV (2008) Abundance of native and non-native lady beetles (Coleoptera: Coccinellidae) in different habitats in Maine. Ann Entomol Soc Am 101:1078-1087

Firlej A, Lucas E, Coderre D, Boivin G (2010) Impact of host behavioural defenses on parasitization efficacy of a larval and adult parasitoid. BioControl 55:339-348

Gardiner MM, Landis DA (2007) Impact of intraguild predation by adult Harmonia axyridis (Coleoptera: Coccinellidae) on Aphis glycines (Hemiptera: Aphididae) biological control in cage studies. Biol Control 40:386-395

Gardiner MM, Landis DA, Gratton C, Schmidt N, O'Neal M, Mueller E, Chacon J, Heimpel GE, DiFonzo CD (2009) Landscape composition influences patterns of native and exotic lady beetle abundance. Divers Distrib 15:554-564

Goeden RD, Louda SM (1976) Biotic interference with insects imported for weed control. Annu Rev Entomol 21:325-342

Gordon RD (1985) The Coccinellidae (Coleoptera) of America north of Mexico. J New York Entomol Soc 93:1-91

Grez AA (1997) Effect of habitat subdivision on the population dynamics of herbivorous and predatory insects. Revista Chilena de Historia Natural 70:481-490

Grez AA, Zaviezo T, Díaz S, Camousseigt B, Cortés G (2008) Effects of habitat loss and fragmentation on the abundance and species richness of aphidophagous beetles and aphids in experimental alfalfa landscapes. Eur J Entomol 105:411-420

Grill CP, Moore AJ, Brodie ED III (1997) The genetics of phenotypic plasticity in a colonizing population of the ladybird beetle, Harmonia axyridis. Heredity 78:261-269

Harmon JP, Stephens E, Losey J (2007) The decline of native coccinellids (Coleoptera: Coccinellidae) in the United States and Canada. J Insect Conserv 11:85-94

Harwood JD, Ricci C, Romani R, Pitz KM, Weir A, Obrycki JJ (2006) Prevalence and association of the laboulbenialean fungus Hesperomyces virescens (Laboulbeniales: Laboulbeniaceae) on coccinellid hosts (Coleopera: Coccinellidae) in Kentucky, USA. Eur J Entomol 103:799-804

Hautier L, Gregoire JC, de Schauwers J, Martin GS, Callier P, Jansen JP, de Biseau JC (2008) Intraguild predation by Harmonia axyridis on coccinellids revealed by exogenous alkaloid sequestration. Chemoecology 18:191-196

Heimpel GE, Frelich LE, Landis DA, Hopper KR, Hoelmer KA, Sezen Z, Asplen MK, Wu KM (2010) European buckthorn and Asian soybean aphid as components of an extensive invasional meltdown in North America. Biol Invasions 12:2912-2931

Hesler LS, Kieckhefer RW (2008) Status of exotic and previously common native coccinellids (Coleoptera) in South Dakota landscapes. J Kans Entomol Soc 81:29-49
Hodek I, Honěk A (1996) Ecology of Coccinellidae. Kluwer Academic Publishers, Dordrecht

Hodek I, Michaud JP (2008) Why is Coccinella septempunctata so successful? (A point-of-view). Eur J Entomol 105:1-12

Hoogendoorn M, Heimpel GE (2002) Indirect interactions between an introduced and a native ladybird beetle species mediated by a shared parasitoid. Biol Control 25:224-230

Hoogendoorn M, Heimpel GE (2004) Competitive interactions between an exotic and a native ladybeetle: a field cage study. Entoml Exp Appl 111:19-28

Horn DJ (1991) Potential impact of Coccinella septempunctata on endangered Lycaenidae (Lepidoptera) in northwestern Ohio, USA. In: Polgár L, Chambers RL, Dixon AFG, Hodek I (eds) Behaviour and impact of Aphidopaga. SPB Academic Publishing, The Hague, pp 159-162

Kajita Y, Evans EW (2009) Ovarian dynamics and oosorption in two species of predatory lady beetles (Coleoptera: Coccinellidae). Physiol Entomol 34:185-194

Kajita Y, Evans EW (2010) Relationships of body size, fecundity, and invasion success among predatory lady beetles (Coleoptera: Coccinellidae) inhabiting alfalfa fields. Ann Entomol Soc Am 103:750-756

Kajita Y, Takano F, Yasuda H, Agarwala BK (2000) Effects of indigenous ladybird species (Coleoptera: Coccinellidae) on the survival of an exotic species in relation to prey abundance. Appl Entomol Zool 35:473-479

Kajita Y, Takano F, Yasuda H, Evans EW (2006a) Interactions between introduced and native predatory ladybirds (Coleoptera, Coccinellidae): factors influencing the success of species introductions. Ecol Entomol 31:58-67

Kajita Y, Yasuda H, Evans EW (2006b) Effects of native ladybirds on oviposition of the exotic species, Adalia bipunctata (Coleoptera: Coccinellidae), in Japan. Appl Entomol Zool 41:57-61

Kajita Y, Evans EW, Yasuda H (2009) Reproductive responses of invasive and native predatory lady beetles (Coleoptera: Coccinellidae) to varying prey availability. Environ Entomol 38:1283-1292

Koch RL, Galvan TL (2008) Bad side of a good beetle: the North American experience with Harmonia axyridis. BioControl 53:23-35

Koch RL, Hutchison WD, Venette RC, Heimpel GE (2003) Susceptibility of immature monarch butterfly, Danaus plexippus (Lepidoptera: Nymphalidae: Danainae), to predation by Harmonia axyridis (Coleoptera: Coccinellidae). Biol Control 28:265-270

Koch RL, Carrillo MA, Venette RC, Cannon CA, Hutchison WD (2004) Cold hardiness of the multicolored Asian lady beetle (Coleoptera: Coccinellidae). Environ Entomol 33:815-822

Koch RL, Venette RC, Hutchison WD (2005) Influence of alternate prey on predation of monarch butterfly (Lepidoptera: Nymphalidae) larvae by the multicolored Asian lady beetle (Coleoptera: Coccinellidae). Environ Entomol 34:410-416

Koch RL, Venette RC, Hutchison WD (2006) Invasions by Harmonia axyridis (Pallas) (Coleoptera: Coccinellidae) in the western Hemisphere: implications for South America. Neotrop Entomol 35:421-434 
Komai T (1956) Genetics of ladybeetles. Adv Genet 8:155-189

Komai T, Hosino Y (1951) Contributions to the evolutionary genetics of the lady-beetle, Harmonia. II. Microgeographic variations. Genetics 36:382-390

Koyama S, Majerus MEN (2008) Interactions between the parasitoid wasp Dinocampus coccinellae and two species of coccinellid from Japan and Britain. BioControl 53:253-264

Krafsur ES, Obrycki JJ, Harwood JD (2005) Comparative genetic studies of native and introduced Coccinellidae in North America. Eur J Entomol 102:469-474

Kryltsov AI (1956) Geographical variability of lady-birds (Coleoptera, Coccinellidae) in north Kirghisia. Entomol Obozr 35:771-781

Labrie G, Lucas E, Coderre D (2006) Can developmental and behavioral characteristics of the multicolored Asian lady beetle Harmonia axyridis explain its invasive success? Biol Invasions 8:743-754

Labrie G, Coderre D, Lucas E (2008) Overwintering strategy of multicolored Asian lady beetle (Coleoptera: Coccinellidae): cold-free space as a factor of invasive success. Ann Entomol Soc Am 101:860-866

LaMana ML, Miller JC (1996) Field observations on Harmonia axyridis Pallas (Coeloptera: Coccinellidae) in Oregon. Biol Control 6:232-237

Laparie M, Lebouvier M, Lalouette L, Renault D (2010) Variation of morphometric traits in populations of an invasive carabid predator (Merizodus soledadinus) within a sub-Antarctic island. Biol Invasions 12:3405-3417

Lawson Handley L-J, Estoup A, Thomas CE, Lombaert E, Facon B, Aebi A, Evans DM, Roy HE (2011) Ecological genetics of invasive alien species. BioControl. doi: 10.1007/s10526-011-9386-2

Liebherr JK, Krushelnycky PD (2007) Unfortunate encounters? Novel interactions of native Mecyclothorax, alien Trechus obtusus (Coleoptera: Carabidae), and Argentine ant (Linepithema humile, Hymenoptera: Formicidae) across a Hawaiian landscape. J Insect Conserv 11:61-73

Lombaert E, Guillemaud T, Cornuet JM, Malausa T, Facon B, Estoup A (2010) Bridgehead effect in the worldwide invasion of the biocontrol harlequin ladybird. PLOS ONE 5: Art. No. e9743

Louda SM, Pemberton RW, Johnson MT, Follett PA (2003) Nontarget effects-the Achilles' Heel of biological control? Retrospective analyses to reduce risk associated with biocontrol introductions. Annu Rev Entomol 48:365-396

Lucas E (2005) Intraguild predation among aphidophagous predators. Eur J Entomol 102:351-364

Lucas E, Gagne I, Coderre D (2002) Impact of the arrival of Harmonia axyridis on adults of Coccinella septempunctata and Coleomegilla maculata (Coleoptera: Coccinellidae). Eur J Entomol 99:457-463

Lucas E, Vincent C, Labrie G, Chouinard G, Fournier F, Pelletier F, Bostanian NJ, Coderre D, Mignault M-P, Lafontaine P (2007) The multicolored Asian lady beetle Harmonia axyridis (Coleoptera: Coccinellidae) in Quebec agroecosystems ten years after its arrival. Eur J Entomol 104:737-743

Lynch LD, Hokkanen HMT, Babendreier D, Bigler F, Burgio G, Gao Z-H, Kuske S, Loomans A, Menzler-Hokkanen I, Thomas MB, Tommasini G, Waage JK, van Lenteren JC, Zeng Q-Q (2001) Insect biological control and non-target effects: a European perspective. In: Wajnberg E, Scott JK,
Quimby PC (eds) Evaluating indirect ecological effects of biological control. CABI Publishing, UK, pp 99-126

MacArthur RH, Wilson EO (1967) The theory of island biogeography. Princeton University Press, Princeton

Majerus MEN (1997) Interspecific hybridization in ladybirds (Col.: Coccinellidae). Entomol Rec 109:11-23

Majerus M, Strawson V, Roy H (2006) The potential impacts of the arrival of the harlequin ladybird, Harmonia axyridis (Pallas) (Coleoptera: Coccinellidae), in Britain. Ecol Entomol 31:207-215

Marco DA, Páez SA, Cannas SA (2002) Species invasiveness in biological invasions: a modelling approach. Biol Invasions 4:193-205

Martins CBC, Almeida LM, Zonta-de-Carvalho RC, Castro CF, Pereira RA (2009) Harmonia axyridis: a threat to Brazilian Coccinellidae? Revista Brasiliera de Entomologica 53:663-671

Matsumoto Y, Sakuratani Y (2006) Interspecific relationship between an exotic ladybird beetle, Adalia bipunctata (Coleoptera: Coccinellidae), and native predacious ladybird beetle. Jpn J Environ Entomol Zool 17:67-75

Michaud JP (2002) Invasion of the Florida citrus ecosystem by Harmonia axyridis (Coleoptera: Coccinellidae) and asymmetric competition with a native species, Cycloneda sanguinea. Environ Entomol 31:827-835

Michie LJ, Mallaerd F, Majerus MEN, Jiggins FM (2010) Melanic through nature or nurture: genetic polymorphism and phenotypic plasticity in Harmonia axyridis. J Evol Biol 23:1699-1707

Minchin D (2010) A swarm of the seven-spot ladybird Coccinella septempunctata (Coleoptera: Coccinellidae) carried on a cruise ship. Eur J Entomol 107:127-128

Moser SE, Obrycki JJ (2009) Competition and intraguild predation among three species of coccinellids (Coleoptera: Coccinellidae). Ann Entomol Soc Am 102: 419-425

Nakashima Y, Senoo N (2003) Avoidance of ladybird trails by an aphid parasitoid Aphidius ervi: active period and effects of prior oviposition experience. Entomol Exp Appl 109:163-166

Niemala J, Spence JR (1991) Distribution and abundance of an exotic ground beetle (Carabidae) — a test of community impact. Oikos 62:351-359

Niemala J, Spence JR, Carcamo H (1997) Establishment and interactions of carabid populations: an experiment with native and introduced species. Ecography 20:643-652

Nóia M, Borges I, Soares AO (2008) Intraguild predation between the aphidophagous ladybird beetles Harmonia axyridis and Coccinella undecimpunctata (Coleoptera: Coccinellidae): the role of intra and extraguild prey densities. Biol Control 46:140-146

Obrycki JJ, Kring TJ (1998) Predaceous Coccinellidae in biological control. Annu Rev Entomol 43:295-321

Obrycki JJ, Giles KL, Ormord AM (1998a) Experimental assessment of interactions between larval Coleomegilla maculata and Coccinella septempunctata (Coleoptera: Coccinellidae) in field cages. Environ Entomol 27:12801288

Obrycki JJ, Giles KL, Ormord AM (1998b) Interactions between an introduced and indigenous coccinellid species at different prey densities. Oecologia 117:279-285 
Obrycki JJ, Elliott NC, Giles KL (2000) Coccinellid introductions: potential for and evaluation of non-target effects. In: Follett PA, Duan JJ (eds) Nontarget effects of biological control. Kluwer Academic Publisher, Boston, pp 127-145

Osawa N (2005) The effect of prey availability on ovarian development and oosorption in the ladybird beetle Harmonia axyridis (Coleoptera: Coccinellidae). Eur J Entomol 102:503-511

Pell JK, Baverstock J, Roy HE, Ware RL, Majerus MEN (2008) Intraguild predation involving Harmonia axyridis: a review of current knowledge and future perspective. BioControl 53:147-168

Prasad RP, Snyder WE (2004) Predator interference limits fly egg biological control by a guild of ground-active beetles. Biol Control 31:428-437

Prasad RP, Snyder WE (2006) Diverse trait-mediated interactions in a multi-predator, multi-prey community. Ecology 87:1131-1137

Prokrym DR, Pike KS, Nelson DJ (1998) Biological control of Diuraphis noxia (Homoptera: Aphididae): implementation and evaluation of natural enemies. In: Quisenberry SS, Peairs FB (eds) Response model for an introduced pest-the Russian Wheat Aphid, Thomas Say Publ Entomol, Entomol Soc Am, pp 183-208

Rana JS, Dixon AFG, Jarosik V (2002) Costs and benefits of prey specialization in a generalist insect predator. $\mathrm{J}$ Anim Ecol 71:15-22

Rand TA, Louda SM (2006) Spillover of agriculturally subsidized predators as a potential threat to native insect herbivores in fragmented landscapes. Conserv Biol 20:1720-1729

Rhule EL, Majerus MEN, Jiggins FM, Ware RL (2010) Potential role of the sexually transmitted mite Coccipolipus hippodamiae in controlling populations of the invasive ladybird Harmonia axyridis. Biol Control 53:243-247

Rhymer JM, Simberloff D (1996) Extinction by hybridization and introgression. Annu Rev Ecol Syst 27:83-109

Riddick EW (2010) Ectoparasitic mite and fungus on an invasive lady beetle: parasite coexistence and influence on host survival. Bull Insectol 63:13-20

Riddick EW, Schaefer PW (2005) Occurrence, density, and distribution of parasitic fungus Hesperomyces virescens (Laboulbeniales: Laboulbeniaceae) on multicolored Asian lady beetle (Coleoptera: Coccinellidae). Ann Entomol Soc Am 98:615-624

Rosenzweig ML (1991) Habitat selection and population interactions: the search for mechanism. Am Nat 137:S5S28

Roy HE, Migeon A (2010) Ladybeetles (Coccinellidae). Chapter 8.4. In: Roques A, Kenis M, Lees D, Lopez-Vaamonde C, Rabitsch W, Rasplus J-Y, Roy D (eds) Alien terrestrial arthropods of Europe. BioRisk 4(1):293-313

Roy HE, Baverstock J, Ware RL, Clark SJ, Majerus MEN, Baverstock KE, Pell JK (2008) Intraguild predation of the aphid pathogenic fungus Pandora neoaphidis by the invasive coccinellid Harmonia axyridis. Ecol Entomol 33:175-182

Roy HE, Lawson Handley L-J, Schonrogge K, Poland RL, Purse BV (2011) Can the enemy release hypothesis explain the success of invasive alien predators and parasitoids? BioControl. doi:10.1007/s10526-011-9349-7
Roy K, Jablonski D, Valentine JW (2002) Body size and invasion success in marine bivalves. Ecol Lett 5:163-167

Ruesink JL, Parker IM, Groom MJ, Kareiva PM (1995) Reducing the risks of nonindigenous species introductions. BioScience 45:465-477

Sakuratani Y (1994) New record of Adalia bipunctata (Coleoptera: Coccinellidae) from Japan. Jpn J Entomol 62:627-628

Sakuratani Y (2002) Alien ladybird species. In: Murakami O, Washitani I (eds) Handbook of alien species in Japan. Chijinshokan, Tokyo, p 136

Sakuratani Y, Matsumoto Y, Oka M, Kubo T, Fujii A, Uotani M, Teraguchi T (2000) Life history of Adalia bipunctata (Coleoptera: Coccinellidae) in Japan. Eur J Entomol 97: $555-558$

Sasaji H (1982) New record of Coccinella in Japan. Coleopt News 100:10-13

Sato S, Dixon AFG (2004) Effect of intraguild predation on the survival and development of three species of aphidophagous ladybirds: consequences for invasive species. Agric For Entomol 6:21-24

Sato S, Yasuda H, Evans EW, Dixon AFG (2009) Vulnerability of larvae of two species of aphidophagous ladybirds, Adalia bipunctata Linnaeus and Harmonia axyridis Pallas, to cannibalism and intraguild predation. Entomol Sci 12:111-115

Schaefer PW, Dysart RJ, Specht HB (1987) North American distribution of Coccinella septempunctata (Coleoptera: Coccinellidae) and its mass appearance in coastal Delaware. Environ Entomol 16:368-373

Schellhorn NA, Lane CP, Olson DM (2005) The co-occurrence of an introduced biological control agent (Coleoptera: Coccinella septempunctata) and an endangered butterfly (Lepidoptera: Lycaeides melissa samuelis). J Insect Conserv 9:41-47

Sebolt DC, Landis DA (2004) Arthropod predators of Galerucella calmariensis L. (Coleoptera: Chrysomelidae): an assessment of biotic interference. Environ Entomol 33: 356-361

Shapiro-Ilan DI, Cottrell TE (2005) Susceptibility of lady beetles (Coleoptera: Coccinellidae) to entomopathogenic nematodes. J Invertebr Pathol 89:150-156

Simberloff D, Gibbons L (2004) Now you see them, now you don't!-population crashes of established introduced species. Biol Invasions 6:161-172

Simberloff D, Stiling P (1996) How risky is biological control? Ecology 77:1965-1974

Sloggett JJ, Davis AJ (2010) Eating chemically defended prey: alkaloid metabolism in an invasive ladybird predator of other ladybirds (Coleoptera: Coccinellidae). J Exp Biol 213:237-241

Sloggett JJ, Magro A, Verheggen FJ, Hemptinne J-L, Hutchison WD, Riddick EW (2011) The chemical ecology of Harmonia axyridis. BioControl. doi:10.1007/s10526-0119376-4

Snyder WE, Evans EW (2006) Ecological effects of invasive arthropod generalist predators. Annu Rev Ecol Evol Syst 37:95-122

Snyder WE, Clevenger GM, Eigenbrode SD (2004) Intraguild predation and successful invasion by introduced ladybird beetles. Oecologia 140:559-565 
Soares AO (2010) Coleoptera (Coccinellidae). In: Borges PAV, Costa A, Cunha R, Gabriel R, Gonçalves V, Martins AF, Melo I, Parente M, Raposeiro P, Rodrigues P, Santos RS, Silva L, Vieira P, Vieira V (eds) A list of the terrestrial and marine biota from the Azores. Princípia, Cascais, p 225

Soares AO, Serpa A (2007) Interference competition between ladybird beetle adults (Coleoptera: Coccinellidae): effects on growth and reproductive capacity. Popul Ecol 49:37-43

Soares AO, Coderre D, Schanderl H (2001) Influence of phenotype on fitness parameters of Harmonia axyridis Pallas (Coleoptera: Coccinellidae). Eur J Entomol 98:287-293

Soares AO, Coderre D, Schanderl H (2003) Effect of temperature and intraspecific allometry on predation by two phenotypes of Harmonia axyridis Pallas (Coleoptera: Coccinellidae). Environ Entomol 32:939-944

Soares AO, Coderre D, Schanderl H (2004) Dietary selfselection behavior by the adults of the aphidophagous ladybeetle Harmonia axyridis (Coleoptera: Coccinellidae). J Anim Ecol 73:478-486

Soares AO, Coderre D, Schanderl H (2005) Influence of prey quality on the fitness of two phenotypes of the adults of Harmonia axyridis. Entomol Exp Appl 114:227-232

Soares AO, Borges I, Borges PAV, Labrie G, Lucas E (2008) Harmonia axyridis: what will stop the invader? BioControl 53:127-145

Staines CL Jr, Rothchild MJ, Trumble RB (1990) A survey of the Coccinellidae (Coleoptera) associated with nursery stock in Maryland. Proc Entomol Soc Wash 92:310-313

Stewart LA, Dixon AFG (1989) Why big species of ladybird beetles are not melanic. Funct Ecol 3:165-177

Tan CC (1946) Mosaic dominance in the inheritance of color patterns in the lady-bird beetle, Harmonia axyridis. Genetics 31:195-210

Taylor AJ, Muller CB, Godfray HCJ (1998) Effect of aphid predators on oviposition behavior of aphid parasitoids. J Insect Behav 11:297-302

Tedders WL, Schaefer PW (1994) Release and establishment of Harmonia axyridis (Coleoptera: Coccinellidae) in the southeastern United States. Entomol News 105:228-243

Toda Y, Sakuratani Y (2006) Expansion of the geographical distribution of an exotic ladybird beetle, Adalia bipunctata (Coleoptera: Coccinellidae), and its interspecific relationships with native ladybird beetles in Japan. Ecol Res 21:292-300

Turnock WJ, Wise IL, Matheson FO (2003) Abundance of some native coccinellines (Coleoptera: Coccinellidae) before and after the appearance of Coccinella septempunctata. Can Entomol 135:391-404

Ware R, Majerus MEN (2008) Intraguild predation of immature stages of British and Japanese coccinellids by the invasive ladybird Harmonia axyridis. BioControl 53:169188

Ware R, Yguel B, Majerus M (2009) Effects of competition, cannibalism, and intra-guild predation on larval development of the European coccinellid Adalia bipunctata and the invasive species Harmonia axyridis. Ecol Entomol 34:12-19
Watanabe M (2002) Cold tolerance and myo-inositol accumulation in overwintering adults of a lady beetle, Harmonia axyridis (Coleoptera: Coccinellidae). Eur J Entomol 99:5-9

Weber DC, Lundgren JG (2009) Assessing the trophic ecology of the Coccinellidae: their roles as predators and prey. Biol Control 51:199-214

Wheeler AG Jr, Hoebeke ER (1995) Coccinella novemnotata in northeastern North America: historical occurrence and current status (Coleoptera: Coccinellidae). Proc Entomol Soc Wash 97:701-716

Wheeler AG Jr, Hoebeke ER (2008) Rise and fall of an immigrant lady beetle: is Coccinella undecimpunctata $\mathrm{L}$. (Coleoptera: Coccinellidae) still present in North America? Proc Entomol Soc Wash 110:817-823

Whittaker RJ, Fernández-Palacios JM (2009) Island biogeography: ecology, evolution, and conservation, 2nd edn. Oxford University Press, Oxford

Yasuda H, Shinya K (1997) Cannibalism and interspecific predation in two predatory ladybirds in relation to prey abundance in the field. Entomophaga 42:153-163

Yasuda H, Kikuchi T, Kindlmann P, Sato S (2001) Relationships between attack and escape rates, cannibalism, and intraguild predation in larvae of two predatory ladybirds. J Insect Behav 14:373-384

Yasuda H, Evans EW, Kajita K, Urakawa K, Takizawa T (2004) Asymmetric larval interactions between introduced and indigenous ladybirds in North America. Oecologia 141:722-731

\section{Author Biographies}

Edward W. Evans is a professor of biology at Utah State University (USA) with research emphasis in insect ecology. His research interests lie especially in species interactions within insect communities, invasion ecology, and the ecological bases of biological control, as involving ladybird beetles and other insect natural enemies (predators, parasitoids, and herbivores).

António Onofre Soares is a professor of Ecology at the University of the Azores (Portugal). His research focuses primarily on the ecological bases of biological control. He has worked extensively on ladybird beetles as model species (i) to determine the best conditions for mass rearing, (ii) to assess the vulnerability of these species to biotic interactions, and (iii) to study lethal and sub-lethal effects of pesticides. He is now exploring new ideas on life-history evolution and dynamics of colonization and invasion of ladybird beetles in an island context.

Hironori Yasuda is a professor of animal ecology at Yamagata University (Japan). The focus of his research is community ecology with particular emphasis on species interactions of prey and predators, and on top down and bottom up effects in biological communities. He has a particular interest in the concept of the balance of nature. 